$12-2013$

\title{
The effect of public debt on growth in multiple regimes
}

Andros Kourtellos

Thanasis Stengos

Chih Ming Tan

University of North Dakota, chihming.tan@UND.edu

How does access to this work benefit you? Let us know!

Follow this and additional works at: https://commons.und.edu/ef-fac

Part of the Economics Commons

\section{Recommended Citation}

Andros Kourtellos, Thanasis Stengos, and Chih Ming Tan. "The effect of public debt on growth in multiple regimes" (2013). Economics \& Finance Faculty Publications. 5.

https://commons.und.edu/ef-fac/5

This Article is brought to you for free and open access by the Department of Economics \& Finance at UND Scholarly Commons. It has been accepted for inclusion in Economics \& Finance Faculty Publications by an authorized administrator of UND Scholarly Commons. For more information, please contact und.commons@library.und.edu. 


\title{
The effect of public debt on growth in multiple regimes*
}

\author{
Andros Kourtellos ${ }^{\mathrm{i}}$, Thanasis Stengos ${ }^{\mathrm{ii}}$, and Chih Ming Tan ${ }^{\mathrm{iii}}$ \\ ${ }^{\mathrm{i} U n i v e r s i t y ~ o f ~ C y p r u s ~}$ \\ ii University of Guelph \\ iii University of North Dakota
}

August 24, 2013

\begin{abstract}
We employ a structural threshold regression methodology to investigate the heterogeneous effects of debt on growth using public debt as a threshold variable as well as several other plausible variables. Our methodology allows us to address parameter heterogeneity that characterizes cross-country growth data and at the same time account for endogeneity. We find strong evidence for threshold effects based on democracy, which implies that higher public debt results in lower growth for countries in the Low-Democracy regime. Our results are consistent with the presence of parameter heterogeneity in the cross-country growth process due to fundamental determinants of economic growth proposed by the new growth theories.
\end{abstract}

Keywords: parameter heterogeneity, public debt, debt threshold, threshold regression.

JEL Classification Codes: C59, O40, Z12.

*We would like to thank Nicoletta Neophytou for providing outstanding research assistantship. Authors' full addresses: Andros Kourtellos, Department of Economics, University of Cyprus, P.O. Box 537, CY 1678 Nicosia, Cyprus, e-mail: andros@ucy.ac.cy; Thanasis Stengos, Department of Economics, University of Guelph, Guelph, Ontario N1G 2W1, Canada, e-mail: tstengos@uoguelph.ca; and Chih Ming Tan, Department of Economics, College of Business and Public Administration, University of North Dakota, Gamble Hall Room 290, 293 Centennial Drive Stop 8369,Grand Forks, ND 58202-8369, e-mail: chihming.tan@business. und.edu. 


\section{Introduction}

There is a growing concern that current debt trajectories in several economies around the world are not sustainable implying risks to long-term growth and stability. For example, at the end of 2011, Japan's debt-to-GDP of $233 \%$ was the highest debt-to-GDP ratio among the world's developed countries. The US debt-to-GDP ratio reached $102 \%$ after the government's debt ceiling was lifted, and in Europe, the prime example is Greece with a $165.3 \%$ debt-toGDP ratio. The outlook for a number of countries does not look any better under existing fiscal policies. As argued by Cecchetti, Mohanty, and Zampolli (2011a) projections of debtto-GDP ratios look even worse, especially when one takes into account expected future age-related spending.

All this evidence has created an urgent need for policymakers in governments, central banks, and international policy organizations to understand the effects of public debt on economic growth. The fear that investors may interpret the high debt-to-GDP ratios as the result of time inconsistent or inflationary policies has led countries to implement immediate and severe austerity measures on their citizens and adopt fiscal discipline in order to restore their credibility irrespective of the costs in terms of high unemployment, deflation, and the possibility of depression. But is this fear justified for all countries?

In fact, the concerns over the sustainability of public debt levels are grounded in both theory and empirics; see for example Panizza and Presbitero (2013) for a comprehensive survey of the existing literature 1 The theoretical literature has distinguished between the positive short-run effects of accumulating public debt in order to enact counter-cyclical policies and potential negative long-run growth effects from high levels of debt. For example, Elmendorf and Mankiw (1999) emphasize the potential crowding out effect of higher public debt on private investment although their back-of-the-envelope calculations suggest that the growth effects from crowding out may be modest.

A key focus of the current literature on the effects of public debt on economic performance has been the attempt to identify nonlinear and in particular threshold effects. The idea is that debt levels that are above a particular threshold value may have different implications for growth compared to more moderate levels of debt. There exists theoretical work that suggests that the effect of public debt on growth may, in fact, be nonlinear so that there may exist an optimal level of public debt; see Checherita-Westphal, Hallett, and

\footnotetext{
${ }^{1}$ The literature review portions of this paper draw heavily from their work.
} 
Rother (2012) and Ghosh, Kim, Mendoza, Ostry, and Qureshi (2012). Using data for OECD countries, Greiner (2011) finds that the optimal level of public debt ranges between $43 \%$ and $63 \%$ of GDP.

In terms of the empirical literature, a recent prominent study by Reinhart and Rogoff (2010) found that there is generally a weak relationship between government debt and economic growth for countries with debt below 90\% of GDP. However, for countries with debt-to-GDP over 90\%, debt can have adverse consequences on growth. Other studies have attempted to provide a formal test for the $90 \%$ threshold value of Reinhart and Rogoff (2010). For example, Cecchetti, Mohanty, and Zampolli (2011b) and Caner, Grennes, and Koehler-Geib (2010) employ the threshold regression of Hansen (2000) to estimate public debt thresholds. Cecchetti, Mohanty, and Zampolli (2011b) study the effects of public debt on growth using a new dataset on debt levels in 18 OECD countries from 1980 to 2010. Using threshold regression, they find that government debt is bad for growth when it is above the threshold value of $85 \%$ of GDP. Caner, Grennes, and Koehler-Geib (2010) using threshold regression methods on data for a larger set of countries for 1980 to 2008 find that a threshold of $77 \%$ public debt-to-GDP ratio is the critical level after which debt becomes damaging to growth. Relatedly, Minea and Parent (2012) employ the panel smooth threshold regression model of González, Teräsvirta, and Van Dijk (2005) who find that there is a negative effect of public debt on growth when the level of debt is between $90 \%$ and $115 \%$ of GDP.

Current work suffers from a number of conceptual and methodological issues. An important limitation of the recent work has been the failure to adequately account for heterogeneity in the effect of debt on growth, which may arise due to alternative growth theories. Specifically, researchers have been searching for threshold effects of public debt on growth when debt is above or below a particular public debt threshold value. The alternative that has been considered is simply that there is no nonlinearity in the effect of public debt on growth. However, these studies do not investigate other possible threshold variables beyond the debt-to-GDP ratio. But, why would we believe a priori that the effect of public debt on growth is characterized only by excessive levels of debt?

This paper is designed to elucidate our understanding by providing answers to the above questions using an econometric methodology that allows us to deal with parameter heterogeneity more generally. Parameter heterogeneity refers to the idea that the data generating process that describes the cross-country growth process is not common for all observations. For example, theory suggests that other factors besides just the debt-to- 
GDP ratio; e.g., a country's trade openness or institutional quality, are plausible sources of convergence clubs and therefore can be used as threshold variables to sort countries into multiple growth regimes in which countries obey the same growth model.

One approach that deals with the problem of parameter heterogeneity is to use threshold regression (TR) or sample splitting models. In a seminal paper, Durlauf and Johnson (1995) employed a sample splitting (specifically, a regression tree) approach to uncover multiple growth regimes in the data. Following a similar strategy Papageorgiou (2002) organized countries into multiple growth regimes using the trade share and Tan (2010) classified countries into development clubs using the average expropriation risk 2 A key goal of this paper therefore is to evaluate the strongest evidence for a particular factor (be it the debtto-GDP ratio, institutions, etc) out of a large set of plausible candidates, in the context of threshold regression models, as being the most plausible threshold variable to characterize the heterogeneous effects of public debt on growth and thereby, consequently, organizing countries into multiple growth regimes.

One difficulty with the recent work on the effects of public debt on growth is that they largely ignore the problem of endogeneity in the threshold variable. This is important because, as Kourtellos, Stengos, and Tan (2013) argue, if the threshold variable is endogenous, the above approaches will yield inconsistent parameter estimates for the regime-specific partial effects. In fact, there is strong evidence that variables such as public debt, trade, and institutions are endogenous; see Panizza and Presbitero (2012), Frankel and Romer (1999) and Acemoglu, Johnson, and Robinson (2001), respectively. In this paper, we therefore model parameter heterogeneity using the structural threshold regression (STR) model, which was proposed by Kourtellos, Stengos, and Tan (2013). Threshold regression models classify observations into stochastic processes depending on whether the observed value of a threshold variable is above (or below) a threshold value. A key feature of STR is that it allows for the endogeneity of the threshold variable as well as for the endogeneity of regressors. Our analysis augments the Solow growth model with the debt-to-GDP ratio and investigates the possibility of multiple growth regimes in the data using a comprehensive set of growth determinants as threshold variables including among others the debt-to-GDP ratio, institutions, ethnic fractionalization, and trade openness.

\footnotetext{
${ }^{2}$ An alternative approach employs semiparametric models based on nonparametric smooth functions to identify general nonlinear growth patterns. Notable examples include Durlauf, Kourtellos, and Minkin (2001) and Mamuneas, Savvides, and Stengos (2006).
} 
In terms of our findings, we find strong evidence for threshold effects based on democracy, as a proxy for institutional quality, in the effect of debt on growth. More precisely, our findings show that there exists a critical level of democracy under which more public debt leads to lower growth, ceteris paribus. While the focus of the existing literature has been on whether there exist threshold effects of public debt on growth (tipping-points), this paper suggests that, once a rich set of alternative theories are considered, there is very little evidence for such nonlinearities. Instead, our findings suggest that the effect of public debt on growth depends on a country's democratic institutions. When a country's institutions are below a particular quality level, then, more public debt leads to lower growth (all else equal). However, if a country's institutions are of sufficiently high quality, then, public debt is growth neutral. Our paper therefore shifts the focus of research on the long-run effects of public debt towards the presence of parameter heterogeneity in the cross-country growth process due to fundamental determinants of economic growth proposed by the new growth theories.

The rest of the paper is organized as follows. Section 2 describes our empirical methodology and Section 3 describes our data. In Section 4 we present the main results of the paper and finally, in Section 5, we conclude.

\section{Empirical methodology}

\subsection{The augmented Solow growth regression model}

We start our investigation of the effect of debt, $d_{i}$, on economic growth using a Solow growth model augmented with the debt-to-GDP ratio. This model assumes that the structural growth process for country $i$ obeys a linear model and is common across countries. Specifically, we employ a three-period pooled panel to estimate a linear regression of the average growth rate of real GDP per capita. Our analysis focuses on the coefficient of debt, $\alpha_{d}$, which estimates the effect of debt on growth, controlling for a set of standard Solow growth determinants, $S_{i}$.

$$
g_{i}=\beta^{\prime} X_{i}+e_{i}=\alpha_{S}^{\prime} S_{i}+\alpha_{d} d_{i}+e_{i}, i=1,2, \ldots, N,
$$


where $S_{i}$ is a vector of regressors that includes the Solow variables, namely the logarithm of population growth plus 0.05 (Population Growth), the logarithm of the average investment to GDP ratio (Investments), the logarithm of the average years of secondary and tertiary schooling for male population over 25 years of age (Schooling), and the logarithm of real GDP per worker in the initial year of each 10-year period (Initial Income). $S_{i}$ also includes a constant and a time trend. $e_{i t}$ is an i.i.d. error term. In this paper we instrument the Solow variables using their lagged values.

Next, we describe a STR model for growth that deals with the problem of parameter heterogeneity.

\subsection{Threshold Solow growth model}

We now describe the STR model by Kourtellos, Stengos, and Tan (2013), that allows for endogeneity in the slope regressors $X_{i t}$ as well as the threshold variable 3 This model can be viewed as a generalization of the simple threshold regression framework of Hansen (2000) and Caner and Hansen (2004) to allow for the endogeneity of the threshold variable and regime specific heteroskedasticity.

Consider a threshold variable $q_{i t}$ such as public debt that can organize the observations into regimes and define the following indicator function

$$
I\left(q_{i} \leq \gamma\right)= \begin{cases}1 & \text { iff } q_{i} \leq \gamma: \text { Regime } 1 \\ 0 & \text { iff } q_{i}>\gamma: \text { Regime } 2\end{cases}
$$

and $I\left(q_{i}>\gamma\right)=1-I\left(q_{i} \leq \gamma\right)$. In this paper, we assume that $q_{i}$ can be any non-constant variable that belongs to the set of determinants $X_{i}$. We assume that $q_{i}$ is endogenous so that the reduced form equation that determines which regime applies takes the form

$$
q_{i}=\pi_{q}^{\prime} Z_{i}+v_{q i}
$$

It is worth noting that the above reduced form equation is analogous to the selection

\footnotetext{
${ }^{3}$ The threshold model of Caner and Hansen (2004) (IVTR) allows only for the endogeneity of the slope regressors and maintains the assumption of the exogeneity of the threshold. STR reduces to IVTR when $\kappa=0$.
} 
equation that appears in the literature on limited dependent variable models. However, there is one important difference. While in sample selection models, we observe the assignment of observations into regimes but the (threshold) variable that drives this assignment is taken to be latent, here, it is the opposite; we do not know which observations belong to which regime (i.e., we do not know the threshold value), but we can observe the threshold variable.

Following Kourtellos, Stengos, and Tan (2013) we can generalize (2.1) to allow for two regimes as follows:

$$
g_{i}=\beta^{\prime} X_{i}+\delta^{\prime} X_{i} I\left(q_{i} \leq \gamma\right)+\kappa \lambda_{i}(\gamma)+\varepsilon_{i}
$$

where $E\left(\varepsilon_{i} \mid Z_{i}\right)=0$.

The term $\lambda_{i}(\gamma)$ is a scalar variable that involves an inverse Mills ratio term for each regime in order to restore the conditional mean zero property of the errors. In particular, $\lambda_{i t}(\gamma)$ is defined as follows:

$$
\lambda_{i}(\gamma)=\lambda_{1 i}(\gamma) I\left(q_{i} \leq \gamma\right)+\lambda_{2 i}(\gamma) I\left(q_{i}>\gamma\right),
$$

with $\lambda_{1}\left(\gamma-Z_{i}^{\prime} \pi_{q}\right)=-\frac{\phi\left(\gamma-Z_{i}^{\prime} \pi_{q}\right)}{\Phi\left(\gamma-Z_{i}^{\prime} \pi_{q}\right)}$ and $\lambda_{2}\left(\gamma-Z_{i}^{\prime} \pi_{q}\right)=\frac{\phi\left(\gamma-Z_{i}^{\prime} \pi_{q}\right)}{1-\Phi\left(\gamma-Z_{i}^{\prime} \pi_{q}\right)}$. The functions $\phi(\cdot)$ and $\Phi(\cdot)$ are the normal pdf and cdf, respectively.

Finally, note that the coefficients $\beta$ are the coefficients of the second regime, that is $\beta=\beta_{2}$ and $\delta$ is the difference between the coefficients of regime $1, \beta_{1}$ and regime $2, \beta_{2}$; that is, $\delta=\beta_{1}-\beta_{2}$. Equation (2.4) reduces to the linear growth model in equation (2.1) when $\delta=\kappa=0$.

The estimation of the threshold parameter is based on a concentrated least squares method while the slope coefficients are obtained using 2SLS or GMM. The asymptotic distribution of the threshold parameter $\gamma$ is nonstandard as it involves two independent Brownian motions with two different scales and two different drifts. Confidence intervals are provided by an inverted likelihood ratio approach; see Kourtellos, Stengos, and Tan (2013).

Finally, we test the null hypothesis of a linear model against the alternative of a threshold for each candidate threshold variable, $H_{0}: \delta=0$. We do so by employing the sup Wald test of Kourtellos, Stengos, and Tan (2013), which is an extension of the Davies (1977) Sup 
test to the GMM framework 4 Since the threshold parameter, $\gamma$, is not identified under the null hypothesis of a linear model (i.e. no threshold effect), the p-values are computed by a bootstrap method, which relies on the arguments of Hansen (1996). Specifically, the p-values are computed by a bootstrap that fixes the regressors from the right-hand side of equation (2.4) and generating the bootstrap dependent variable from the distribution $N\left(0, \widehat{\varepsilon}_{i t}^{2}\right)$, where $\widehat{\varepsilon}_{i t}$ is the demeaned residual from the estimated STR model.

\section{Data}

We employ a balanced 10-year period panel dataset covering 82 countries in 1980-89, 199099, and 2000-2009. The three 10-year growth periods allow us to exploit the panel structure of the data and at the same time average out business cycle effects. The dependent variable is computed as the growth rate of real per capita GDP over the time interval sampled from PWT 7.0.

We next describe the set of candidate threshold variables that we consider in addition to the Solow variables and the debt-to-GDP ratio (Public Debt). We include (i) three policy variables; i.e., a measure of trade Openness (the average ratio for each period of exports plus imports to GDP), the log of the average inflation rate (plus one) for each period (Inflation), and a measure of the size of Government relative to the economy (log of the average ratio for each period of government consumption net of outlays on defense and education to GDP), (ii) two measures of institutions; i.e., a measure of the extent of institutionalized Democracy and a measure of the extent of institutionalized constraints on the decision making powers of chief executives (Executive Constraints), and a measure of ethnolinguistic fractionalization (Language), (iii) two geographic variables; i.e., the percentage of a country's land area that is classified as tropical or subtropical (Tropics) and the percentage of a country's land area within $100 \mathrm{~km}$ of an ice-free coast ( $L C R 100 \mathrm{~km}$ ), and, finally, (iv) two demographic variables; i.e., the $\log$ of the average Life Expectancy and the log of the average total fertility rate (Fertility) for each period.

Table 1 presents summary statistics for the pooled data. The variables are drawn from various sources. A detailed description of the variables and their sources is given in Table

\footnotetext{
${ }^{4}$ For robustness purposes we also employed the threshold sup test by Hansen (2000) that ignores the issues of endogeneity and generally found similar results.
} 
A1 of the Appendix.

\section{Results}

We present results for our STR model with the Solow model augmented with public debt as the regime-specific linear model as described in equation (2.4). Table 2 shows in the first two columns the results of a test of the existence of a threshold effect against the null of global linearity for each of the candidate threshold variables described in Section (3) above.

Of the 15 potential candidates, 9 cases; i.e., Initial Income, Schooling, Investments, Population Growth, Fertility, Life Expectancy, Inflation, Tropics, and Democracy, resulted in a rejection of the null. Significantly, there is very little evidence that Public Debt is a good threshold variable for sample splitting. At least for this sample of countries, therefore, there seems to be little evidence of nonlinearity in the effects of public debt on growth. However, there is strong evidence of parameter heterogeneity as suggested by the significant threshold effects obtained using several threshold variables other than the debt-to-GDP ratio.

Table 3 shows the estimate for the threshold value for each of the 9 threshold variables, the associated $90 \%$ confidence interval for the threshold value, the number of observations for each of the two regimes that come from splitting the sample according to each of these threshold variables, and the associated $J$ statistic for the STR model using each of these threshold variables, respectively.

Each of these 9 threshold variables therefore constitutes a potential STR model for the data. Hence, we need to select the model that best fits the data. We do so according to the $J$ criterion. As Table 3 shows, the $J$ criterion is minimized when Democracy is the threshold variable. Hence, we present our findings for the model that splits the sample into a LowDemocracy regime (i.e., countries with Democracy scores below 4.5) and a High-Democracy regime (i.e., countries with Democracy scores above 4.5) in Table 4. The threshold estimate of 4.5 corresponds to Malaysia in period 2 and Nepal in period 3 and the lower and upper bounds of the $90 \%$ confidence interval, [2.949, 4.799], correspond to Philippines in period 1 and Brazil in period 1, respectively. Table 5 shows the the exact sample of countries that fall within each regime and for each period as well as the Democracy scores.

The findings from this STR model are quite striking and point to parameter 
heterogeneity in the sense that the effect of debt on growth depends on democracy. All else equal, higher public debt results in lower growth for countries in the Low-Democracy regime. The coefficient to public debt for this regime is negative and strongly significant at the $1 \%$ level. However, for countries with better quality institutions; i.e., countries in the

High-Democracy regime, public debt has no significant effect on growth. We should also note that countries in the Low-Democracy regime tend to have, on average, higher public debt levels than those in the High-Democracy countries. The mean public debt level for countries in the Low-Democracy regime is around 0.8. In this sense, our results reflect those in the existing literature that suggest that more highly indebted countries are also the ones that tend to experience more negative growth effects from higher levels of debt. However, our findings highlight that the threshold effects that are important in determining the effect of debt on growth are governed by institutions rather than the level of debt itself. Interestingly, the Low-Democracy regime is also characterized by lower growth and income compared to the High-Democracy regime.

\section{Conclusion}

This paper contributes to an important contemporary debate on the relationship between public debt and long-run economic performance. The focus of the existing literature has been on whether there exist nonlinear effects of public debt on growth. Is there a critical level of public debt such that over it, more public debt leads to lower growth, all else equal? The findings in this paper suggest that, once a rich set of alternative theories are considered, there is very little evidence for such nonlinearities. Instead, our findings suggest that the relationship between public debt and growth is mitigated crucially by the quality of a country's institutions. When a country's institutions are below a particular quality level, then, more public debt leads to lower growth (all else equal). However, if a country's institutions are of sufficiently high quality, then, public debt is growth neutral. Our paper therefore shifts the focus of research on the long-run effects of "high levels" of public debt towards its interplay with the deep (fundamental) determinant of growth as recently proposed by the new growth theories. 
Table 1: Descriptive Statistics

This table presents the summary statistics for our dataset.

Growth

Initial Income

Lag of Initial Income

Schooling

$\mathrm{L}$ ag of schooling

Investments

Lag of Investments

Population Growth

Lag of Population Growth

Fertility

Lag of fertility

Life Expectancy

Lag of Life Expectancy

Public Debt

Lag of Public debt

Government

Lag of Government

Inflation

Lag of Inflation

Openness

Lag of openness

Democracy

Lag of Democracy

Executive Constraints

Lag of Executive Constraints

LCR100km

Tropics

Language

$\begin{array}{rrrr}\text { Mean } & \text { Std Dev } & \text { Max } & \text { Min } \\ 0.013737 & 0.02296 & 0.083383 & -0.09946 \\ 8.423263 & 1.266566 & 10.71059 & 5.868249 \\ 8.335907 & 1.232224 & 10.54767 & 5.779916 \\ 0.598071 & 0.768791 & 1.970172 & -2.18351 \\ 0.320655 & 0.901583 & 1.901029 & -2.66267 \\ 3.046038 & 0.351779 & 3.891546 & 1.87323 \\ 3.055552 & 0.394586 & 4.312729 & 1.743324 \\ -2.71142 & 0.160957 & -2.38471 & -3.2289 \\ -2.69098 & 0.16542 & -2.27681 & -3.08358 \\ 1.165151 & 0.501702 & 2.051261 & 0.188966 \\ 1.27774 & 0.521549 & 2.057247 & 0.153579 \\ 4.152884 & 0.176415 & 4.395388 & 3.656394 \\ 4.129947 & 0.179433 & 4.376214 & 3.614339 \\ 0.725291 & 0.626556 & 5.59726 & 0.087895 \\ 0.660963 & 0.609409 & 6.405994 & 0.030556 \\ 2.195023 & 0.439004 & 3.560925 & 1.056177 \\ 2.192095 & 0.477742 & 3.694487 & 1.014359 \\ 2.298081 & 1.167341 & 7.571372 & -1.95183 \\ 2.33869 & 1.193889 & 8.258299 & -1.45953 \\ 66.51136 & 36.48778 & 199.8575 & 9.768346 \\ 61.00657 & 35.80411 & 180.0895 & 9.697868 \\ 5.742649 & 3.834012 & 10 & 0 \\ 5.021545 & 4.167344 & 10 & 0 \\ 4.958977 & 2.047979 & 7 & 1 \\ 4.512398 & 2.332962 & 7 & 1 \\ 0.458926 & 0.361177 & 1 & 0 \\ 0.428233 & 0.425988 & 1 & 0 \\ 0.38244 & 0.297867 & 0.898015 & 0.002113\end{array}$




\section{Table 2: Threshold tests}

This table presents sup Wald tests for the null hypothesis that the linear Solow growth model augmented by the debt-gdp-ratio in equation (2.1) against the alternative hypothesis of the threshold model in equation (2.4). ***, **, and * denote significance at $1 \%, 5 \%$, and $10 \%$, respectively. All models include constant and trend.

$\begin{array}{llr}\text { Threshold Variable } & \text { sup Wald } & \text { Boot p-value } \\ \text { Initial Income } & 53.575^{*} & 0.057 \\ \text { Schooling } & 43.1849^{* * *} & 0.002 \\ \text { Investments } & 30.1235^{*} & 0.067 \\ \text { Population growth } & 57.804^{* *} & 0.015 \\ \text { Fertility } & 51.9421^{* *} & 0.037 \\ \text { Life expectancy } & 81.4932^{* * *} & 0.000 \\ \text { Public Debt } & 16.4969 & 0.517 \\ \text { Government } & 20.2704 & 0.29 \\ \text { Inflation } & 28.7319^{*} & 0.066 \\ \text { Openness } & 25.9372 & 0.131 \\ \text { Democracy } & 31.7114^{*} & 0.096 \\ \text { Executive constraints } & 21.1275 & 0.202 \\ \text { Tropics } & 42.1866^{* * *} & 0.006 \\ \text { LCR100km } & 21.5703 & 0.208 \\ \text { Language } & 20.2187 & 0.235\end{array}$




\section{Table 3: Threshold tests}

This table shows the point estimate of the threshold parameter along with the associated the $90 \%$ confidence interval, the sample size of two growth regimes, and the $J$ statistic for the STR models that rejected the null of the linear model in Table 2

$\begin{array}{llrrrr}\text { Threshold Variable } & \text { threshold estimate } & 90 \% \text { Confidence Interval } & n^{\text {low }} & n^{\text {High }} & J \text { statistic } \\ \text { Initial Income } & 6.93585 & {[6.9258,7.4708]} & 36 & 210 & 2.3 \mathrm{E}-21 \\ \text { Schooling } & 0.95985 & {[0.4689,1.3219]} & 163 & 83 & 6.39 \mathrm{E}-21 \\ \text { Investments } & 2.729622 & {[2.7296,2.7476]} & 35 & 211 & 5.89 \mathrm{E}-22 \\ \text { Population growth } & -2.87913 & {[-2.9211,-2.5471]} & 54 & 192 & 1.17 \mathrm{E}-18 \\ \text { Fertility } & 1.067608 & {[0.8776,1.2866]} & 109 & 137 & 1.7 \mathrm{E}-19 \\ \text { Life expectancy } & 3.97159 & {[3.9706,3.9716]} & 43 & 203 & 9.52 \mathrm{E}-22 \\ \text { Inflation } & 2.776564 & {[1.7656,2.8246]} & 192 & 54 & 3.38 \mathrm{E}-21 \\ \text { Democracy } & 4.599 & {[2.949,4.799]} & 90 & 156 & 1.58 \mathrm{E}-22 \\ \text { Tropics } & 0.443 & {[0,0.967]} & 129 & 117 & 9.57 \mathrm{E}-21\end{array}$


Table 4: STR estimation

This table presents the estimation of the STR model of Kourtellos, Stengos, and Tan (2013) using Democracy as a threshold variable. All variables are instrumented using their lagged values. It also presents the TR model of Hansen (2000) that ignores endogeneity. The last two columns report the GMM and LS results for the global estimation that ignores the presence of a threshold. The means of the variables are also reported for each regime. ${ }^{* *},{ }^{* *}$, and ${ }^{*}$ denote significance at $1 \%, 5 \%$, and $10 \%$, respectively.

Method

Threshold Estimate

$90 \%$ Confidence Interval

$J$ statistic

STR-GMM
4.500
$[2.949,4.799]$
$1.577 \mathrm{E}-22$

$1.577 \mathrm{E}-22$

Low High

Initial Income

Schooling

Investments

$\ddot{c o}$
Population growth

Public debt

Const

Trend

IMR-kappa

Number of obs

Means

Growth

Public debt

Initial Income

Schooling

Investments

Population growth

Democracy

\begin{tabular}{ll}
0.0023 & $-0.0147^{* * *}$ \\
$(0.0052)$ & $(0.0031)$ \\
0.0056 & $0.0083^{*}$ \\
$(0.0050)$ & $(0.0046)$ \\
0.0060 & -0.0042 \\
$(0.0069)$ & $(0.0103)$ \\
-0.0132 & $-0.0811^{* * *}$ \\
$(0.0514)$ & $(0.0237)$ \\
$-0.0109^{* * *}$ & 0.0040 \\
$(0.0036)$ & $(0.0045)$ \\
-0.0571 & -0.0680 \\
$(0.1110)$ & $(0.0490)$ \\
-0.0005 & -0.0001 \\
$(0.0040)$ & $(0.0017)$ \\
$-0.0063^{* * *}$ \\
\multicolumn{2}{c}{$0.0017)$}
\end{tabular}

90

156

$(0.0017)$

\section{TR-LS \\ 4.600 \\ $[1.2,5.6]$}

Low

0.0013

(0.0047)

0.0047

(0.0049)

$0.0173^{* * *}$

(0.0057)

0.0283

(0.0341)

$-0.0121^{* * *}$

(0.0031)

0.0200

(0.0638)

0.0040

$(0.0033)$

$\begin{array}{ll}0.0052 & 0.0187 \\ 0.8288 & 0.6656 \\ 7.5315 & 8.9378 \\ 0.1268 & 0.8700 \\ 2.9927 & 3.0768 \\ -2.6149 & -2.7671 \\ 1.1737 & 8.3786\end{array}$

155
91
High

$\begin{array}{lll}-0.0118^{* * *} & -0.0047^{* *} & -0.0032^{*} \\ (0.0023) & (0.0022) & (0.0019) \\ 0.0099^{* * *} & 0.0056^{*} & 0.0062^{* *} \\ (0.0037) & (0.0033) & (0.0029) \\ 0.0116^{*} & 0.0061 & 0.0187^{* * *} \\ (0.0064) & (0.0051) & (0.0039) \\ -0.0630^{* * *} & -0.0554^{* * *} & -0.0197^{*} \\ (0.0144) & (0.0164) & (0.0109) \\ -0.0028 & -0.0004 & -0.0071^{* * *} \\ (0.0032) & (0.0029) & (0.0022) \\ -0.0928^{* *} & -0.1227^{* * *} & -0.0738^{* * *} \\ (0.0363) & (0.0383) & (0.0282) \\ 0.0003 & 0.0020 & 0.0028 \\ (0.0017) & (0.0020) & (0.0018) \\ & & \end{array}$

$\begin{array}{ll}0.0050 & 0.0189 \\ 0.8270 & 0.6656 \\ 7.5454 & 8.9387 \\ 0.1314 & 0.8721 \\ 2.9906 & 3.0786 \\ -2.6178 & -2.7664 \\ 1.2114 & 8.4030\end{array}$

Linear-GMM Linear-LS 
Table 5: Low- and High-Democracy regimes

e with democracy scores greater than 4.5 ) for each period.

\begin{tabular}{|c|c|c|c|c|}
\hline \multirow{2}{*}{\multicolumn{4}{|c|}{ Europe }} & \multirow[b]{2}{*}{ Latin America and the Caribbean } \\
\hline & & & & \\
\hline Austria & (H) 10 & (H) 10 & (H) 10 & Argentina \\
\hline Belgium & (H) 10 & (H) 10 & (H) 9.4 & Bolivia \\
\hline Denmark & (H) 10 & (H) 10 & (H) 10 & Brazil \\
\hline Finland & (H) 10 & (H) 10 & (H) 10 & Chile \\
\hline France & (H) 8.4 & (H) 9 & (H) 9 & Colombia \\
\hline Greece & (H) 8.8 & (H) 10 & (H) 10 & Costa Rica \\
\hline Ireland & (H) 10 & (H) 10 & (H) 10 & Dominican Republic \\
\hline Italy & (H) 10 & (H) 10 & (H) 10 & Ecuador \\
\hline Netherlands & (H) 10 & (H) 10 & (H) 10 & Guatemala \\
\hline Norway & (H) 10 & (H) 10 & (H) 10 & Guyana \\
\hline Portugal & (H) 9.8 & (H) 10 & (H) 10 & Honduras \\
\hline Spain & (H) 9.8 & (H) 10 & (H) 10 & Jamaica \\
\hline Sweden & (H) 10 & (H) 10 & (H) 10 & Mexico \\
\hline United Kingdom & (H) 10 & (H) 10 & (H) 10 & $\begin{array}{l}\text { Nicaragua } \\
\text { Panama }\end{array}$ \\
\hline Offshoots & & & & Paraguay \\
\hline Australia & (H) 10 & (H) 10 & (H) 10 & Peru \\
\hline Canada & (H) 10 & (H) 10 & (H) 10 & Trinidad \&Tobago \\
\hline New Zealand & (H) 10 & (H) 10 & (H) 10 & Uruguay \\
\hline United States & (H) 10 & (H) 10 & (H) 10 & Venezuela \\
\hline East Asia and the Pacific & & & & Sub-Saharan Africa \\
\hline Indonesia & (L) 0 & (L) 0.7 & (H) 7.6 & Benin \\
\hline Japan & (H) 10 & (H) 10 & (H) 10 & Botswana \\
\hline Korea Republic of & (L) 1.75 & (H) 7.2 & (H) 8 & Burundi \\
\hline Malaysia & (H) 5 & (L) 4.5 & (L) 4.4 & Cameroon \\
\hline Papua New Guinea & (L) 4 & (L) 4 & (L) 4 & Central African Republic \\
\hline Philippines & (L) 3 & (H) 8 & (H) 8 & Congo Republic of \\
\hline Thailand & (L) 3.2 & (H) 7.7 & (H) 6.6 & Cote d'Ivoire \\
\hline Europe and Central Asia & & & & $\begin{array}{l}\text { Gabon } \\
\text { Gambia The }\end{array}$ \\
\hline Turkey & (H) 5.7 & (H) 8.7 & (H) 8 & Ghana \\
\hline Middle East and North Africa & & & & $\begin{array}{l}\text { Kenya } \\
\text { Lesotho }\end{array}$ \\
\hline Algeria & (L) 0.1 & (L) 0.7 & (L) 2.2 & Malawi \\
\hline Cyprus & (H) 10 & (H) 10 & (H) 10 & Mali \\
\hline Egypt & (L) 0 & (L) 0 & (L) 0.5 & Mauritania \\
\hline Iran & (L) 0 & (L) 1.2 & (L) 1.6 & Niger \\
\hline Israel & (H) 9 & (H) 9.1 & (H) 10 & Senegal \\
\hline Morocco & (L) 0 & (L) 0 & (L) 0 & Sierra Leone \\
\hline Syria & (L) 0 & (L) 0 & (L) 0 & South Africa \\
\hline Tunisia & (L) 0 & (L) 0.7 & (L) 1 & Swaziland \\
\hline South Asia & & & & $\begin{array}{l}\text { Togo } \\
\text { Zambia }\end{array}$ \\
\hline Bangladesh & (L) 0 & (H) 5.4 & (H) 4.8 & Zimbabwe \\
\hline India & (H) 8 & (H) 8.5 & (H) 9 & \\
\hline Nepal & (L) 1.8 & (H) 5.2 & (L) 4.5 & \\
\hline Pakistan & (L) 1.6 & (H) 7 & (L) 1.2 & \\
\hline Sri Lanka & (H) 6 & (H) 6 & (H) 6.6 & \\
\hline
\end{tabular}

\begin{tabular}{|c|c|c|}
\hline 1980-89 & 1990-99 & 2000-09 \\
\hline I) 5 & (H) 7.1 & \\
\hline & (H) 9 & (H) 8.2 \\
\hline (H) 4.7 & (H) 8 & (H) 8 \\
\hline (L) 1 & (H) 8 & (H) 9.4 \\
\hline (H) 8 & (H) 7.9 & (H) 7 \\
\hline (H) 10 & (H) 10 & (H) 10 \\
\hline (H) 6 & (H) 6.6 & (H) 8 \\
\hline (H) 8.6 & (H) 8.9 & (H) 5.8 \\
\hline (L) 2 & (H) 5.6 & (H) 8 \\
\hline (L) 0 & (H) 4.8 & (H) 6 \\
\hline (H) 5.6 & (H) 6.1 & (H) 7 \\
\hline (H) 10 & (H) 9.3 & (H) 9 \\
\hline (L) 1.2 & (L) 3.8 & (H) 8 \\
\hline (L) 0.625 & (H) 7 & (H) 8.3 \\
\hline & (H) 8.6 & (H) 9 \\
\hline & (H) & (H) 7.9 \\
\hline (H) & (L) & (H) 9 \\
\hline (H) 8.6 & (H) 9.3 & (H) 10 \\
\hline $\begin{array}{r}\text { (H) } 4.6 \\
\text { (H) } 9\end{array}$ & $\begin{array}{l}\text { (H) } 10 \\
\text { (H) } 8.1\end{array}$ & $\begin{array}{l}\text { (H) } 10 \\
\text { (H) } 5.3\end{array}$ \\
\hline & & \\
\hline $\begin{array}{r}\text { (L) } 0 \\
\text { (H) } 6.3\end{array}$ & $\begin{array}{l}\text { (H) } 6 \\
\text { (H) } 7.3\end{array}$ & $\begin{array}{r}\text { (H) } 6.4 \\
\text { (H) } 8\end{array}$ \\
\hline (L) 0 & (L) 0.25 & (L) 4 \\
\hline ( $\mathrm{L}$ & (L) & (L) 1 \\
\hline (L) & (L) & (L) 2.2 \\
\hline (L) 0 & (L) 3.45 & (L) 0 \\
\hline (I) & (L) 0 & \\
\hline (L) 0 & & (L) 0.4 \\
\hline (H) 7.1 & (L) 3.2 & (L) 0 \\
\hline (L) 0.6 & (L) 1.6 & (H) 7.2 \\
\hline (L) 0 & (L) & \\
\hline (L) 0 & (H) & \\
\hline (L) 0 & (L) & \\
\hline (L) 0 & Н) 5.825 & (H) 6.8 \\
\hline (L) 0 & (L) 0 & (L) 0.4 \\
\hline (L) & (L) 4.4 & (H) 5.9 \\
\hline (L) 2 & (L) 2 & (H) 7.7 \\
\hline (L) 0 & (L) 1.25 & (H) 5.9 \\
\hline (H) 7 & (H) 8.33 & (H) 9 \\
\hline (L) 0 & (L) 0 & (L) 0 \\
\hline (L) 0 & L) 0 . & (L) 1 \\
\hline L) 0 & (L) & (H) 5.2 \\
\hline (L) 2.7 & (L) 0.1 & (L) 1. \\
\hline
\end{tabular}

Sri Lanka

$1.6 \quad$ (H) 7

(1) 


\section{References}

Acemoglu, A., S. Johnson, and J. Robinson, 2001, The Colonial Origins of Comparative Development : An Empirical Investigation, American Economic Review 91, 1369-1401.

Caner, Mehmet, Thomas Grennes, and Fritzi Koehler-Geib, 2010, Finding the tipping point when sovereign debt turns bad, Policy Research Working Paper Series 5391, The World Bank.

Caner, M., and B. Hansen, 2004, Instrumental variable estimation of a threshold model, Econometric Theory 20, 813-843.

Cecchetti, S., M. Mohanty, and F. Zampolli, 2011a, The future of public debt, in S. Gokarn, ed.: Challenges to central banking in the context of the financial crisis . pp. 183-217 (Academic Foundation: New Delhi).

Cecchetti, Stephen G., M. S. Mohanty, and F. Zampolli, 2011b, The real effects of debt, Working paper, Bank for International Settlements (BIS).

Checherita-Westphal, C., A. H. Hallett, and P. Rother, 2012, Fiscal sustainability using growth-maximising debt targets, Working Paper Series 1472, European Central Bank.

Davies, R. B., 1977, Hypothesis testing when a nuisance parameter is present only under the alternative, Biometrika 64, 247-254.

Durlauf, S., and P. Johnson, 1995, Multiple regimes and cross-country growth behavior, Journal of Applied Econometrics 10, 365-384.

Durlauf, S., A. Kourtellos, and A. Minkin, 2001, The local solow growth model, European Economic Review 15, 928-940.

Elmendorf, D. W., and G. N. Mankiw, 1999, Government debt, in J. B. Taylor, and Woodford M., ed.: Handbook of Macroeconomicsvol. 1 pp. 1615?-1669.

Frankel, J., and D. Romer, 1999, Does trade cause growth?, American Economic Review 89, 379-399.

Ghosh, A. R., J. I. Kim, E. G. Mendoza, J. D. Ostry, and M. S. Qureshi, 2012, Fiscal fatigue, fiscal space and debt sustainability in advanced economies, Economic Journal (forthcoming). 
González, A., T. Teräsvirta, and D. Van Dijk, 2005, Panel smooth transition regression models, Working Paper Series in Economics and Finance 604, Stockholm School of Economics.

Greiner, A., 2011, Economic growth, public debt and welfare: Comparing three budgetary rules, German Economic Review 12, 205?-222.

Hansen, B. E., 1996, Inference when a nuisance parameter is not identified under the null hypothesis, Econometrica 64, 413-430.

— , 2000, Sample splitting and threshold estimation, Econometrica 68, 575-603.

Kourtellos, A., T. Stengos, and C. M. Tan, 2013, Structural threshold regression, Working paper, University of Cyprus, University of North Dakota, and University of Guelph.

Mamuneas, T., A. Savvides, and T. Stengos, 2006, Economic development and the return to human capital: A smooth coefficient semiparametric approach, Journal of Applied Econometrics 21, 111-132.

Minea, A., and A. Parent, 2012, Is high public debt always harmful to economic growth? reinhart and rogoff and some complex nonlinearities, Working Papers 8, Association Francaise de Cliometrie.

Panizza, Ugo, and Andrea F. Presbitero, 2012, Public debt and economic growth: Is there a causal effect?, UNCTAD and The Graduate Institute, Working Paper.

Panizza, U., and A. F. Presbitero, 2013, Public debt and economic growth in advanced economies: A survey, Swiss Journal of Economics and Statistics 149, 175-204.

Papageorgiou, C., 2002, Trade as a threshold variable for multiple regimes, Economics Letters $77,85-91$.

Reinhart, C. M., and K. S. Rogoff, 2010, Growth in time of debt, American Economic Review Papers and Proceedings 100, 573-578.

Tan, C. M., 2010, No one true path: Uncovering the interplay between geography, institutions, and fractionalization in economic development, Journal of Applied Econometrics 25, 1100-1127. 


\section{Table A1: Data Appendix}

\section{Variable}

Time trend

Growth

Initial Income

Population Growth Rates

Investment

Schooling

Debt

$\sqsupseteq$

\section{Government}

Inflation

Openness

Life Expectancy

Fertility

\section{Description}

Time trend variable for the periods 1980-89, 1990-99 and 2000-2009.

Growth rate of real per capita GDP in chain series for the periods 1980-89, 1990-99 and 2000-2009. Source: PWT 7.0.

Logarithm of real per capita GDP in chain series at 1980, 1990, 2000. Lagged values correspond to 1975,1985 and 1995. Source: PWT 7.0.

Logarithm of average population growth rates plus 0.05 for the periods 1980-89, 1990-99 and 2000-2009. Lagged values correspond to 1975-79, 1985-89 and 1995-1999. Source: PWT 7.0.

Logarithm of average ratios over each period of investment to real GDP per capita for the periods 1980-89, 1990-99 and 2000-2009. Lagged values correspond to 1975-79, 1985-89 and 1995-1999. Source: PWT 7.0.

Logarithm of average years of male secondary and tetriary school attainment (25+) in 1980, 1990, and 1999. Lagged values correspond to 1975, 1985 and 1995. Source: Barro and Lee (2000).

Public debt to GDP for the periods 1980-89, 1990-99 and 2000-2009. Lagged values correspond to 1975-79, 1985-89 and 1995-1999. Source: IMF, Debt Database Fall 2011 Vintage

Logarithm of average ratios for each period of government consumption to real GDP per capita for the periods 1975-79, 1985-89 and 1995-1999 and 2000-2009. Lagged values correspond to 1975-79, 1985-89 and 1995-1999. Source: PWT 7.0

Logarithm of average inflation plus 1 for the periods 1980-89, 1990-99 and 2000-2009. Lagged values correspond to 1975-79, 1985-89 and 1995-1999. Source: Worldbank

Average ratios for each period of exports plus imports to real GDP per capita for the periods 1980-89, 1990-99 and 2000-2009. Lagged values correspond to 1975-79, 1985-89 and 1995-1999. Source: PWT 7.0.

Log of average life expectancy at birth for the periods 1980-89, 1990-99 and 2000-2009. Lagged values correspond to 1975-79, 1985-89 and 1995-1999. Source: World Bank

Logarithm of the average total fertility rate (births per woman) in 1980-89, 1990-99 and 2000-2009. Lagged values correspond to 1975-79, 1985-89 and 1995-1999. Source: World Bank. 


\section{Table A1 continued}

\section{Variable \\ Description}

Executive Constraints A measure of the extent of institutionalized constraints on the decision making powers of chief executives. This variable ranges from one to seven where higher values equal a greater extent of institutionalized constraints on the power of chief executives. This variable is calculated as the average for the periods 1980-89, 1990-99 and 2000-2009. Lagged values correspond to 1975-79, 1985-89 and 1995-1999. Source: Polity IV

Democracy

A measure of the extent of institutionalized democracy, presence of institutions and procedures, existence of institutionalized constraints on the exercise of power by the executive, and guarantee of civil liberties to all citizens. This variable ranges from one to ten where higher values equal a greater extent of institutionalized democracy. This variable is calculated as the average for the periods 1970-79, 1980-89, 1990-99 and 2000-2009. Lagged values correspond to 1975-79, 1985-89 and 1995-1999. Source: Polity IV

Tropics

LCR100km

Eastern Religion

Measure of linguistic fractionalization based on data describing shares of languages spoken as mother tongues. Source: Alesina, A., A. Devleeschauwer, W. Easterly, S. Kurlat, and R. Wacziarg (2003).

Percentage of land area classified as tropical and subtropical via the in Koeppen-Geiger system. Source: The Center for International Development at Harvard University

Percentage of a country's land area within 100km of an ice- free coast. Source: The Center for International Development at Harvard University

Eastern Religion share in 1970 and 2000 expressed as a fraction of the population. It includes Chinese Universists, Confucians, Neoreligionists, Shintos, and Zoroastrians (Parsis). Source: World Christian Encyclopedia 